accidents in which safety belts were worn. Analysis of 600 accidents in which 837 drivers or front-seat passengers were wearing safety belts at the time of the accidents indicated that serious injuries were reduced by about 80 per cent and overall reduction in injuries was about 50 per cent. Six accidents on motorways during the past $2 \frac{1}{2}$ years were attributed to spray obscuring a driver's vision and problems involving splashing and production of spray by commercial vehicles are being investigated. A preliminary study has shown that the front wheols are particularly important in producing spray because they genorally run in a thicker film of water than the rear wheels, and that the pattern of distribution of spray behind the vehicle depends largely on its shape. Work on road pavements is mainly dirceted at the construction and observation of full-scale experimental roads, generally on routes carrying heavy traffic, and to theoretical and field studies of the stresses and deflexions in multi-layer pavements and the influence on them of repeated loadings. In the experimental section constructed in 1957 on the Al at Alconbury Hill the best sections continue to be those with 4 in. asphalt surfaces on a 9 -in. lean concreto base and on a 6 -in. asphalt base. Studies are in progress on the amount of control testing that should be carried on largo road construction projects, to assess the practical limits for the number of tests, the man-power required to earry out the testing, and the cost of testing in relation to the total cost of each project. The first study suggests that tentative proposals made by the Laboratory are likely to be suitable. To determine the effect of wet weather on the construction of earthworks and to provide some indication of the amount of working time likely to be lost through wet weather, records of the utilization of plant at major earthwork sites have been collected to compare the actual performance each day with the performance during dry weather. Weather at the site has been recorded or records are being obtained from nearby stations of the Meteorological Office. Computer programmes are now available for carrying out the calculations involved in the Road Research Laboratory's hydrographic method of sower design. The Laboratory is also attempting to supply more precise information on the loads imposed on bridges by moving vehicles. This is required in estimating the fatigue life of the structure, and a short-term study is being made of the way in which traffic flow data can be converted into traffic loading data, and a long-term collation of information on vehiclo axle weights, using electronic weighbridges at selected sites. The effects of temperature, croep and shrinkage on the performance of a structure are being investigated by measurements on a number of bridges, including the Hammersmith Flyover and the Medway Bridge, and the results have indicated how the behaviour of a structure can be affected by its form and environment.

\title{
USE OF WHOLE-BODY COUNTERS IN RADIOLOGICAL PROTECTION
}

"T HE Use of Whole-body Counter's in Radiological Protection" was the title of a symposium held at the Middlesex Hospital Medical School on April 7, 1964. It was the eighth in a series sponsored by the Joint Health Physics Committee* and on this occasion was organized for the Committee by the Radiological Protection Service. The proceedings were divided into two sessions, the first being devoted to a roview of the development of wholebody counters and an account of experience in their use over a poriod of more than six yoars at two centres undertaking this work in the United Kingdom, and the second to reports of some special problems encountered in several laboratories. Mr. W. Binks (Radiological Protection Service) acted as chairman of the first session and Prof. F. W. Spiers (University of Leeds) of the second.

In his opening address to the first session Prof. Spiers (University of Leeds) traced the history of the development of whole-body counters from the early work by Schlundt, Barker and Flinn (1929), and Schlundt, Nerancy and Morris (1933), using ionization chambers, to the highly sophisticated apparatus of the present day utiliz. ing scintillation dotectors and multi-channel analysers (Tablo 1).

From this it could be seen that, after Schlundt et al. had made improvements in the ionization-chamber method, there was an additional improvement in sensitivity with the advent of high-pressure ionization chambers, bringing the sensitivity in the region necessary for the measurement of the natural $\gamma$-ray emission of the body. The use of large scintillation counters in 1956 brought about a further increase in the sensitivity and it was this order of sensitivity that had provided the health physicist with a powerful tool for measuring body radioactivity far below the maximum permissible values.

Prof. Spiers stressed that, for a high detection efficiency, both high counting rates and large signal-to-background

* The Joint Health Physics Committee consists of representatives of the British Institute of Radiology, the British Occupational Hygiene Society, the Central Electricity Generating Board, the Faculty of Radiologists, the Hospital Physicists' Association, the Institute of Physics and the Physical Protection and the United Kingdom Atomic Energy Authority. ratio were important, as could be seen from the well-known formula :

$$
\begin{aligned}
S . E .(\text { as percentage of } S) & =\frac{100}{S}\left(\frac{B}{t_{B}}+\frac{B+S}{t_{S}}\right)^{\frac{1}{2}} \\
& =\frac{100}{(a S)^{\frac{1}{2}}}\left(\frac{1}{t_{B}}+\frac{1+a}{t_{S}}\right)^{\frac{1}{2}}
\end{aligned}
$$

(where $S . E$. is the standard error as a percentage of $S$, the counts per sec due to the source, $B$ is the counts per sec due to background, $a=S / B$, and background observations are made for $t_{B}$ sec and source observations for $t_{S} \mathrm{sec}$ ). In order to make the standard error small, $S$ should be large, which meant a physically large detector should be used, and $a$ should be increased as far as possible by reducing $B$.

Table 1. Development of Wholk-Body Codnting SInCe 1929 Approximate limit of detection (or standard

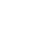

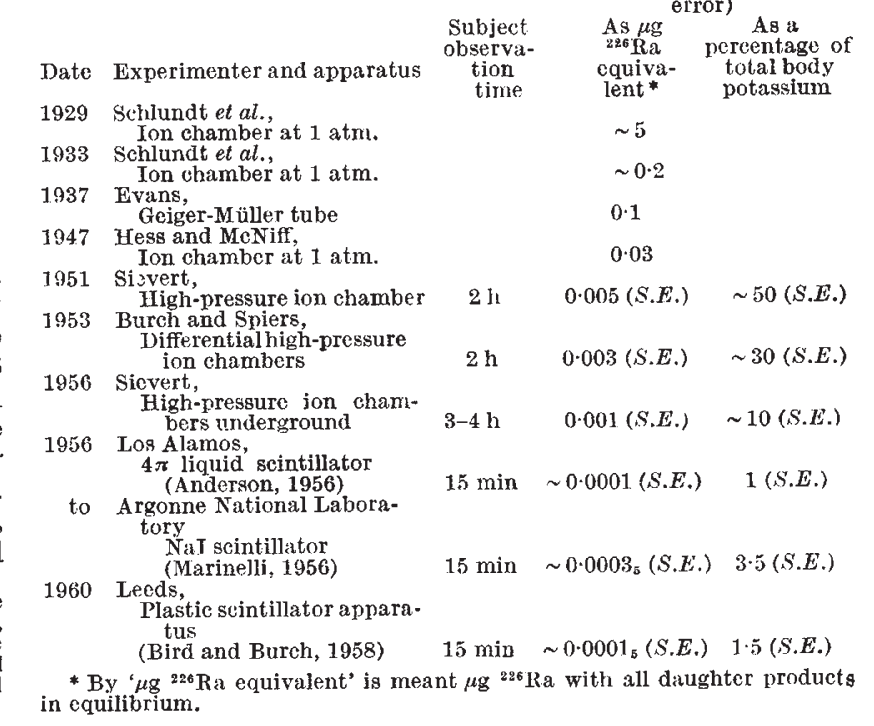


Prof. Spiers referred to a number of different materials, from chalk to lead, which had been used to provide the shield against environmental radiation in order to reduce $B$ (Trott, Parnell, Hodt and Entwistle, 1963, and Wilson, 1964). He considered that attention must also be directed to the problems of other sources of contamination both within the scintillator and its container, also in the bases and resistance chains of the photomultiplior tubes, and other miscellancous parts (Marinelli, Miller, May and Rose, 1962 , and Wilson, 1964). Given a sufficiently sensitive detector and adequate background shielding, statistical accuracy equivalent to about 1 or 2 per cent of the natural ${ }^{40} \mathrm{~K}$ content of the body could be achieved. This same order of accuracy was also possible for repeated obsorvations on one person, but there were limitations. when determining absolute amounts of radioactivity in the body. Most of the difficulties arose because the activity was distributed about the body and offered a different geometry in each configuration of detector and subject. Moreover, this distribution frequently changed with time after the intake of radioactive material into the body. It was very difficult, therefore, to deviso 'phantoms' containing calibrating solutions which approximated at all closely to the in vivo distribution, except with radionuclides which dispersed uniformly throughout the whole body. Exceptionally, it might be possible to carry out in vivo calibrations with isotopes of the radioactive material concerned, for example, ${ }^{42} \mathrm{~K}$ for ${ }^{40} \mathrm{~K}$, and this could increase the accuracy very considerably.

Another important aspect of the accuracy of measurement concerned the overall stability of the apparatus. This became specially important for long observation times and when computer analysis of the results was to be used. One solution to this was to build some form of automatic stabilization into the equipment (Dudley, 1962). As to the choice of detector in any particular instance, this would depend very much on the circumstances and the problem in hand. For rapid screening of large numbers of individuals there was great merit in the use of the large plastic and liquid scintillators, though it must be remembered that time for changing and preparation of the individual was also required, and the actual observation time was only part of the whole operation.

Finally, Prof. Spiers commented that it must be generally conceded that in protection work the sodium iodide crystal detector offered most advantages with regard to higher energy resolution and, therefore, the identification of different radionuclides in the body. Where any large body of people was concerned, it would seem that a simple fast scheme could be worked out using large plastic or liquid scintillators for initial screening purposes. Persons with significant activities could then be passed on to a sodium iodide counter for detailed study.

In his paper entitled "Some Applications of Body" Radioactivity Measurements to Radiological Protection at Harwell", Dr. J. Rundo (Atomic Energy Research Establishment, Harwell) stated that there wero two applications for whole-body counters at Harwell, namely, the measurement of body radioactivity of persons who had been involved in accidents with radioactive materials and the undertaking of more fundamental studies on the distribution of radioactive material in body tissues and its elimination from the body. The apparatus used had been described in detail elsewhere (Rundo, 1958). During the past five years the number of suspected accident cases oxamined at Harwell had amounted on average to only 18 a year. By no means all these had been found to be contaminated and the main effort, therefore, had been devoted to careful investigations of a few cases. With regard to observations on the distribution of radioactive material in the body, this could be achieved in three ways, namely: (a) by scanning, that is, movement of the detector over the surface of the body; $(b)$ by a single large crystal close to an organ of the body; and (c) by use of a slit collimator to givo a profile curve.
Three cases which illustrated the types of problems encountered in radiological protection were described. All three cases concerned the accidental inhalation of radioactive materials, which Dr. Rundo believed was the predominant mode of entry into the body in most practical circumstances; a view which was later endorsed by others in the discussion. The first case involved ${ }^{90} \mathrm{Sr}$ carbonate (Rundo and Williams, 1961). Measuromonts wore made of body radioactivity, and also of the activity in urine. Tho significant feature emerging from the results was that if the body radioactivity had been inferred from the initial urine moasurements, using data given in the report of Committee II of the International Commission on Radiological Protection (I.C.R.P. II, 1959) for the biological half-life, the estimated body-burden would have been much larger than that actually moasured in tho whole-body counter. Therefore, it was clear that, wherever possible, it: was necessary to havo excretion data supplemented by measurements of total-body radioactivity by external counting. The second case (Rundo, 1964) concerned an individual who had inhaled dust generated whilo grinding and polishing irradiated uranium. The accident was detected when widespread contamination wals found in the working area. It was demonstrated that a number of radionuclides had been inhaled, and later: it was calculated that the initial dose-rate to the lungs was nearly twice the maximum permissible value of $0.3 \mathrm{rem} /$ week recommended by I.C.R.P., but this decreased by about an order of magnitude in six days. The retention of radioisotopes of $\mathrm{Cs}, \mathrm{Ce}, \mathrm{Ru}$, and $\mathrm{Zr}$ with $\mathrm{Nb}$ was followed with the whole-body counter over several hundred days. The whole-body scan showed that, with the exception of ${ }^{137} \mathrm{Cs}$, all the radionuclides were located in the chest and their activities in that region over a period of time decreased in a manner which was identical with that expected by radioactive decay alone, suggesting that there was little, if any, elimination of these materials from the body. This fact is, of course, quite at variance with the views of I.C.R.P. II that the half-life of particulate material in the lungs is 120 days.

In the third case (Newton, 1963) the accident concerned a man who inhaled dust during maintenance operations on a reactor. The principal contaminants were ${ }^{65} \mathrm{Zn}$ and ${ }_{110} \mathrm{~m} \mathrm{Ag}$, identified from examination of a handkerchief used by the man immodiately after the accident. $H$ is radioactivity was followed by whole-body counting over a period of $2 \mathrm{yr}$. and profile curves were determined. The profile curves indicated that both ${ }^{65} \mathrm{Zn}$ and ${ }^{110 \mathrm{~m}} \mathrm{Ag}$ were transferred almost completely from the lungs within a few days. A widespread distribution of ${ }^{65} \mathrm{Zn}$ in soft tissues was apparent from the early stages, with an appreciable concentration in the liver during the first 100 days. ${ }^{110 \mathrm{~m}} \mathrm{Ag}$ was concentrated in the liver and was eliminated from that organ with a biological half-life of about 50 days. For both silver and zinc the excrotion pattern from the whole body could be described by the sum of two exponential terms. In the case of rine, 27 per cent was eliminated with a biological half-lifo of 18 days and 73 per cent with a half-life of 453 days. Most of the silver (about 85 per cent) disappeared very rapidly with a biological half-life of about one day and 15 per cent with a half-life of $\mathbf{5 2}$ days, that is, not very different from the rate of elimination from the liver.

In none of the cases described had the individual concerned received a significant radiation dose as a result of the incident. This could have been predicted early in the investigation and the prolonged studies had been made solely to determine the behaviour in the body of the various radionuclides concerned. In answer to a question, Dr. Rundo said that most of the silver and rinc were excreted in the fæces. There was no measurable excretion of silver in urine. He emphasized that excretion patterns varied considerably botween individuals, as illustrated by measurements of Furchner, Richmond and Trafton (1962) on four people to whom ${ }^{65} \mathrm{Zn}$ was administered orally. 
Table 2. Radioactivity of Various Materials

\begin{tabular}{|c|c|c|c|c|c|c|c|}
\hline \multirow[b]{2}{*}{ Material } & \multicolumn{3}{|c|}{ Radioactivity } & \multicolumn{4}{|c|}{$\begin{array}{l}\text { Primary photon emission in } \\
\text { photons/min.g }\end{array}$} \\
\hline & $\begin{array}{c}\text { Uran- } \\
\text { ium } \\
10^{-14} \\
\text { c. } / \mathrm{g}\end{array}$ & $\begin{array}{l}\text { Thor- } \\
\text { ium } \\
10^{-14} \\
\text { c./g }\end{array}$ & $\begin{array}{l}\text { Potas- } \\
\text { siurn } \\
10^{-6} \\
\mathrm{~g} / \mathrm{g}\end{array}$ & $\begin{array}{l}\text { Uran- } \\
\text { ium }\end{array}$ & $\begin{array}{l}\text { Thor- } \\
\text { ium }\end{array}$ & $\begin{array}{l}\text { Potas- } \\
\text { sium }\end{array}$ & Tot \\
\hline $\begin{array}{l}\text { Brick } \\
\text { Cement } \\
\text { Soil (sample) }\end{array}$ & $\begin{array}{l}75 \\
40 \\
40\end{array}$ & $\begin{array}{r}150 \\
70 \\
120\end{array}$ & $\begin{array}{r}35,000 \\
5,000 \\
\text { Not }\end{array}$ & $\begin{array}{l}3 \cdot 5 \\
1.9\end{array}$ & $\begin{array}{r}10 \cdot 0 \\
4 \cdot 7\end{array}$ & $\begin{array}{l}7 \cdot 4 \\
1 \cdot 1\end{array}$ & $\begin{array}{r}21 \cdot 0 \\
7 \cdot 7\end{array}$ \\
\hline $\begin{array}{l}\text { Chalk (North } \\
\text { Downs) }\end{array}$ & 10 & 3 & $\begin{array}{c}\text { measured } \\
20\end{array}$ & 0.5 & 0.2 & $\begin{array}{l}\text { Very } \\
\text { small }\end{array}$ & 0.7 \\
\hline
\end{tabular}

Reviewing the use of whole-body counters at the Radiological Protection Service, Mr. J. Vennart considered that tho most interesting feature of the equipment was the construction of the low-background laboratories. Early measurements of the local gamma-ray background in 1956 (Vennart, 1957) had indicated that the chalk underlying the site at Belmont, Surrey, where the Radiological Protection Service was situated, had a very low radioactivity. The reason for this could be seen from information he presented showing the concentrations of the principal naturally occurring radioactive materials, uranium, thorium and potassium (potassium due to the naturally occurring isotope ${ }^{40} \mathrm{~K}$ ), in a representative sample of brick, cement, soil and chalk and the primary photon emission in photons $/ \mathrm{min} / \mathrm{g}$ in the material from each radionuclide and for the mixture (Table 2). It showed that the total rate of primary photon emission in brick was 30 times greater than in chalk. As soon as this fact was appreciated, a temporary laboratory was built below ground in the chalk and this was still in use at the present time (Vennart, 1963). The detector consisted of four $4 \frac{1}{2}$-in. $\times 2$-in. sodium iodide crystals placed in line above the body and in a second counter, recently completed, there were four crystals both above and below the body.

The largest group of people measured had been moro than 500 people who had worked in the radium luminizing industry (Vennart, Maycock, Godfrey and Davies, 1964). Twenty of them had been found to have more than the maximum permissiblo body burden, namely, 0.1 uc. of ${ }^{226} \mathrm{Ra}$ (I.C.R.P. II). The majority contained quite trivial amounts of radium and the important foature was that no one who had luminized exclusively since 1941 contained more than half the maximum permissible body burden. The reason for this might be traced to the fact that it was realized in 1939 that there would be a largo increase in the luminizing industry during war-timo and, in view of the sorious injuries known to have occurred among some of the early American workers concerned with luminizing, the occupation of luminizing in Britain had been brought under the medical supervision of the Ministry of Labour. This supervision, besides including regular medical examinations of the workers, had also resulted in tho institution of very simple rules of hygiene in the industry. It was interesting, in view of the present-day efforts in the health and safety field, to seo how effective? these very simple rules had been. The other large series of measurements had been of fission products in members of the population, principally ${ }^{137} \mathrm{Cs}$ (Maycock, Terry, Vennart and Wise, 1960, and Maycock, McCansh and Vennart, 1962), but also during 1961 of ${ }^{131}$ (Vennart, 1962). It had also been possible to measure ${ }^{131} \mathrm{I}$ in the thyroid glands of people living in London following the Windscale Reactor accident in 1957 (Maycock and Vennart, 1958).

During the period that the counter had been in operation (1957-64), body radioactivity of only 85 people had been mensured because of incidents involving the dispersal of radioactive materials, and only six of these had more than one-tenth of the maximum permissible body burden of the radionuclide concerned. The radioactivity of the majority of these people was measured because of uneasiness on the part either of the individual himself or of his employer. In other words, they came mainly to be reassured that there was no radioactivity in their bodies. There remained a doubt as to whether it was only the most apprehensive people, or those employed by the most careful employers, who were referred for measurement of radioactivity, and whether more severely contaminated people had escaped attention. Some justification for this assumption might be obtained from the results of measurements of radioactivity carried out on people at present working in the radium luminizing industry, in which they were selected for measurement more or less at random. In this study, 33 people out of a total of 82 mcasured had contained more than one-tenth of the maximum permissible body burden of radium, which was a much higher proportion than was found in the people referred to tho Radiological Protection Service because of incidents involving radioactive material.

These facts suggested that there should bo more routine measurements of radioactivity of people working with radioactive materials, but not necessarily with high sonsitivity equipment. For the majority of radionuclides which could be measured by detectors placed outside the body, the activities which were of interest could be determined by using very simple apparatus. Significant, activities were often several microcuries, not only because the maximum permissible body burdens were large, but also because the radionuclides were often oliminatod rapidly from the body and, therefore, the intake of maximum permissible body burdens led to radiation doses which were quite trivial by our present standards (Vennart, 1963). In the discussion which followed about this latter point, it was pointed out that the prevention of intake of radioactive matorials by adequate environmental control was also important.

The second session was opened by a papor entitled "The Problem of Extornal Counting of Plutonium at Low Levels in vivo", in which Mr. B. Taylor (Atomic Energy Research Establishment, Harwell) described the difficulties of measuring ${ }^{239} \mathrm{Pu}$ in vivo by detection of the extremely low-intensity $\gamma$-rays emittod. Using a 9-in. $\times$ 6 -in. sodium iodide crystal, the minimum detectable activity of ${ }^{239} \mathrm{Pu}$ in the lung was about $2-3 \mu \mathrm{c}$., while the maximum permissible amount in the lung, corresponding to a dose rate of $0.3 \mathrm{rom} /$ weok, was only $16 \mathrm{nc}$. An alternative method was to measure the $L$ X-rays of uranium, which are emitted following the disintegration of ${ }^{23} \mathrm{Pu}$, with an intensity of about $4 \times 10^{-2}$ photons per $\alpha$-particle. These X-rays, of energjes $13.6 \mathrm{keV}, 16 \cdot 9 \mathrm{keV}$ and $20.2 \mathrm{keV}$, had half-value layers in soft tissue of about $0.4,0.7$ and $1.0 \mathrm{~cm}$ respectively. The half-value layer in bone was only about $0.03 \mathrm{~cm}$, and the determination of ${ }^{239} \mathrm{Pu}$ in bone at levels near the maximurn permissible body burden of $40 \mathrm{nc}$., therefore, appeared unlikely.

Attempts to measure ${ }^{299} \mathrm{Pu}$ in lung had first been made by Roesch and Palmer (1962), using a thin NaI crystal. In these measurements, a large contribution to the background in the energy band of the $L \mathrm{X}$-rays was duo to photomultiplier dark noise. The lower background and superior onergy resolution obtainable with gas-filled proportional counters had led to the adoption of this type of detector at Harwell. A 6-in.-diamoter end-window flow counter constructed from 'Perspex' and containing argon with 10 per cent methane was used with a well-shaped plastic phosphor anti-coincidence shield. The counter background inside a small lead shield 4 in. thick was 1.5 c.p.m. in the energy band $10-22.5 \mathrm{keV}$, and the best energy resolution achieved at $13.4 \mathrm{koV}$ was 11 por cent, which was close to the theoretical minimum value. Because of the high absorption of the X-rays in body tissues, the effects of variation in distribution of the inhaled ${ }^{28}{ }^{\circ} \mathrm{Pu}$ in the lung, and differences in chest-wall thickness between individuals, had made calibration difficult. However, an estimate of the effective depth of the material might be possible by differential measurements of the three X-rays, since their absorption coofficients aro markedly different.

Two further methods of calibration involving human subjects were discussed. The first concerned a case of accidental inhalation of ${ }^{285} \mathrm{U}$. In this case the amount of the material in the lung could be estimated by measure- 
ments of the $186-\mathrm{keV} \gamma$-ray it emitted, using a 9-in. $\times 6$-in. sodium iodide crystal detector. Since ${ }^{235} \mathrm{U}$ also emits the characteristic $L$ X-rays of thorium, the energies of which are close to those emitted following the disintegration of ${ }^{239} \mathrm{Pu}$, it was possible to estimate the sensitivity of the proportional countor for ${ }^{238} \mathrm{Pu}$ in lung. Measurements made with the window of the proportional counter close to the chest of the subject had shown that tho counting rates wore significantly higher than those from two normal subjects with similar potassium and ${ }^{137} \mathrm{Cs}$ contents. The minimum detectable activity was estimated to be $55 \mathrm{nc}$. of ${ }^{23} \mathrm{Pu}$ for a $100-\mathrm{min}$ measurement. An improvement in sensitivity was expected from the use of a larger multiwire counter which had just beon constructed. Xonon was proposed as the filling gas, though considerable purification from krypton impurity (containing ${ }^{85} \mathrm{Kr}$ ) might be required to obtain a sufficiently low background. An alternative method of calibration proposed was the inhalation by volunteer subjects of a 'mock' ${ }^{239} \mathrm{Pu}$. This would consist of an insoluble mixture of three radionuclides of medium atomic number, which decay by electron capture, giving $K \mathrm{X}$-rays of the same energy as the uranium $L$ X-rays emitted following the disintegration of ${ }^{239} \mathrm{Pu}$. Radionuclides which were being considered were ${ }^{85} \mathrm{Sr},{ }^{93} \mathrm{Mo}$, ${ }^{103} \mathrm{Pd}$ and ${ }^{103} \mathrm{Ru}$. Both ${ }^{85} \mathrm{Sr}$ and ${ }^{103} \mathrm{Ru}$ also emit higher-energy $\gamma$-rays, thus enabling the lung content after inhalation to be determined by measurements with a sodium iodide crystal dotector. An advantage of this method was that reasonably high counting rates might bo obtained with the proportional counter, without large radiation doses being received by the volunteer's lungs, since the half-lives of the radionuclides proposed were relatively short.

In his paper entitled "Measurements of Some Long-lived Alpha-Gamma-Emitters in the Thorax" Mr. D. Newton (Harwell) directed attention to the fact that for many $\alpha$-emitters the maximum permissible amounts in lung, corresponding to a dose rate of $0 \cdot 3 \mathrm{rem} /$ week, were only a fow nis. The detection and estimation of such small amounts in vivo might, therofore, be difficult because the $\gamma$-radiation accompanying the $\alpha$-emission is generally of low intensity and in the low-energy region, where the contrifutions from scattered photons arising from ${ }^{40} \mathrm{~K}$ and ${ }^{137} \mathrm{Cs}$ in the body might be difficult to assess. By way of illustration, Mr. Newton described measurements of body radioartivity which were being made on two people who had accidentally inhaled radioactive materials.

The first case involved ${ }^{227} \mathrm{Ac}$, the long-lived parent of a chain of $\alpha$-emitters. The parent emitted no detectable $\gamma$-radiation itself, and its presence in vivo could only be inferred from the $\gamma$-rays emitted by its daughters, ${ }^{227} \mathrm{Th}$ ( 18 days) and ${ }^{223}$ Ra ( 11.7 days) et seq. The activity in the chest was measured with a single 9 -in. $\times 6$-in. sodium iodide crystal placed behind the thorax. The difficulties of calibration were stressed, especially with regard to the excretion of daughter nuclides. For example, it appeared in this case that the ${ }^{233} \mathrm{Ra}$ was excreted more rapidly than the ${ }^{227} \mathrm{Th}$, but estimation of the equilibrium amounts of these daughters was complicated by the similarity of their spectra and the possibility of their being distributed differently in the chest. Between 200 and 800 days after the incident the chest contents of ${ }^{227} \mathrm{Th}$ and ${ }^{223 \mathrm{Ra}}$ wore evidently constant at about 1 nc. and $0 \cdot 6$ nc., respectively, showing that there had been no loss of ${ }^{227}$ Ac during this period, although a small reduction could have been masked by the subject's steeply rising content of ${ }^{137} \mathrm{Cs}$ resulting from nuclear weapons testing. However, measurements of tho subject's whole-body radioactivity made during the first 200 days using the four-crystal spectromoter (Rundo, 1958) had indicated that some of the inhaled material had been eliminated more rapidly.

The second case involved a mixture of ${ }^{231} \mathrm{~Pa}$ with about 7 per cent of its daughter ${ }^{227} \mathrm{Ac}$. Measurements with the single large crystal showod that the chest content of ${ }^{231} \mathrm{~Pa}$ was unchanged between 7 and 300 days after the incident, at about 10 nc. or two-thirds of the maximum permissible amount in lung. The ${ }^{227} \mathrm{Ac}$ content was apparently about $1 \mathrm{nc}$. or one-quarter of the maximum permissible amount in lung, but may have decreased very slightly during the period of observation. In conclusion, Mr. Newton said that the investigations had shown that it was possible to measure about a quarter of the maximum permissible amounts in the lung of ${ }^{227} \mathrm{Ac}$ and ${ }^{231} \mathrm{~Pa}$ with sufficient accuracy for protection purposos. However, there remained a doubt about the exact location of this material within the chest. In neither case was it certain that the activity was depositod solely in the lungs. If it. wero instead in the pulmonary lymph nodes, then lower maximum permissible amounts would presumably apply because of the smaller tissue masses involved. In the discussion, attention was directed to the fact that the long: biological half-lives of these materials in the lung were contrary to Baird's findings with dogs (Baird, Tombropoulos and Park, 1963), and unexpected from tho physiology of the human lung. If the contaminants had been in a! soluble form and deposited in bone, this might explain the different results. Was there any information on the chemical form of the materials, or the presence of activity in the frees? Mr. Nowton replied that nothing was known of the chemical form of the ${ }^{227} \mathrm{Ac}$ inhaled by the first subject and. in the second case, the chemical form of the ${ }^{231} \mathrm{~Pa}$ was not known with certainty: possible compounds were $\mathrm{Pa}_{2} \mathrm{O}_{5}$ and $\mathrm{KPaO}_{3}$. None of the parent nuclides had been found in the frces of either subject, though in the first case. ${ }^{223} \mathrm{Ra}$ had been detected after 100 days.

In a paper entitled "Measurement of Fall-out ${ }^{137} \mathrm{Cs}$ in Infants", by F. W. Spiers and A. R. Wilson (University of Leeds), Mr. Wilson described measurements of ${ }^{137} \mathrm{Cs}$ and ${ }^{40} \mathrm{~K}$ using a detector consisting of four 6 -in. $\times 6$-in. sodium iodide crystals. The crystals wore positioned above and bolow the infant in such a way that the sensitivity of the counter was almost independent of the position and attitude of the infant during the measurement. For a measurement time of $30 \mathrm{~min}$, the standard errors of measuring $1 \mathrm{ne} \cdot{ }^{137} \mathrm{Cs}$ and $8 \mathrm{~g}$ potassium in a new-born infant were respectively \pm 7 per cent and \pm 10 per cent. It had been possible to estimate the turnover of ${ }^{137} \mathrm{Cs}$ in two cases in which the babies had been fed on dried milk. In calculating the turnover time it had been assumed that the newly born baby had the same ${ }^{13{ }^{7}} \mathrm{C}$ concentration per unit mass as the mother. The way in which the observed body content of ${ }^{13} \mathrm{Cs}$ changed with time could be accounted for by assuming a biological half-life of 8 days for one baby and 7 days for the other. Both babies had been measured up to about 30 days old. $\mathrm{Mr}$. Wilson considered that it would have been of interest to study breast-fed babies and older children, but it was very difficult to determine the ${ }^{137} \mathrm{Cs}$ intake in such cases.

The way that the ratio ${ }^{137} \mathrm{Cs} / \mathrm{K}$ changed with time in the two cases was conflicting. In one baby the ratio rose to i maximum in a few weeks, whereas in the other it fell to a minimum at about the same age. Commenting on this in the discussion, Mr. Wilson suggested that the reason for this discrepancy probably lay in calibration and that it was not easy to get a truly representative model when the potassium and ${ }^{137} \mathrm{Cs}$ were varying and also probably undergoing re-distribution in the body. In the discussion, Dr. Rundo briefly described some measurements of body radioactivity which he had made on two children. The ways in which the body content of ${ }^{137} \mathrm{Cs}$ changed with time were consistent with a biological half-life of 10 days for a child measured up to 30 days old and a half-life of 7 days for another measured up to 37 days old. Mr. G. Stott said that he had made measurements of body radioactivity on one child who was 90 days old which showed that the ratio ${ }^{137} \mathrm{Cs} / \mathrm{K}$ was twice that of adults measured at the same time. The radiation dose received would also be about twice that received by adults.

Mr. C. O. Peabody considered the general philosophy of the use of whole-body counters in radiological protection 
in his paper, "The Value of Routine Measurements at the Atomic Energy Establishment, Winfrith". He compared and contrasted the problems and methods of minimizing and measuring exposure to external radiation with those for the internal irradiation produced by radioactive contamination in the body. Where external radiation was concerned the exposure of individual workers was minimized by providing adequate shielding, by controlling working times and by frequent environmental surveys. Finally, the adequacy of protection was further ehecked by the wearing of personal dosemeters, such as film badges. In the case of internal radiation the risk was minimized by the containment of radioactive material, by adequate ventilation, and by environmental monitoring for contamination on surfaces and in the air. There was, however, no system of routine personal dosimetry for internal radiation which was at all comparable in its simplicity and accuracy with that of the film badge in monitoring external radiation. A case could be made for the necd for such a routine system, but it was at present impracticable. The practice generally adopted, and implied in some codes of practice, was that measurements of body radioactivity need be made only when it seemed possible that the person had been exposed to an undue risk of taking radioactive material into the body.

Mr. Peabody went on to consider the problems involved in making routine measurements of body radioactivity. For example, it was necessary to make measurements at realistic intervals of time commensurate with the counting facilities available and with the time for which the subject could be taken away from his work. It was impossible to lay down a standard interval between measurements which would be applicable in all cases, because this depended on the effective half-lifo of the radionuclide in the body. The situation at Winfrith was that there were about 200 people who were exposed to a possible risk and only about 30 per week could be measured in the whole-body counter there. If all these people were measured continuously, therefore, the interval between measurements would be seven weeks and for many of the radionuclides concerned this would be far too long. Accordingly, a programme of continuous measurement of body radioactivity of all people had not been adopted and measurements had been limited to a representative sample of the people concerned. People were chosen for the sample according to their estimated risk of contamination. Unexposed staff such as office workers were used as controls. So far, no person had been found to contain more than a negligible fraction of the maximum permissible body burden of any radionuclide while, for the majority, the only radionuclides detected were ${ }^{40} \mathrm{~K}$ and fall-out ${ }^{137} \mathrm{Cs}$. The system had proved to be advantageous in that it had found a few cases of personnel contamination which had not been previously suspected and, equally important, it had served to reassure staff and supervisors. In the discussion that followed there were several comments about the time taken to prepare an individual for measurement in a whole-body counter. The need for the individual to take a shower bath depended on whether or not the person had been exposed recently to the risk of contamination. It was agreed that it was always necessary to change into clean and previously monitored clothing.

In dealing with "The Usefulness of Routine Measure ments in a Whole-body Counter as a Check on the Effectiveness of Contamination Control", Mr. G. Stott (Dounreay Experimental Reactor Establishment) stated that the principal uses of the whole-body counter at Dounreay had been for routine measurement of body radioactivity of workers, experimental investigations of people who had accidentally acquired radioactive materials in their bodies, measurement of samples taken on environmental surveys and diagnostic tests of thyroid function as a. service to ordinary members of the public in the vicinity of Dounreay. There were about 300 people who might be at risk at the Dounreay Experimental Reactor Establish. ment. These were mostly employed on fuel processing, so the radioactive materials concerned were chiefly fission products. During 1963, when there had been a large increase in fuel processing, extensive air sampling had been undertaken in order to ascertain whether there was any increase in environmental contamination. This showed that the concentration of radioactive materials in the atmosphere had rarely been excessive and the effectiveness of this environmental monitoring with regard to the protection of the workers had been checked by measurements of the body radioactivity in the whole-body counter.

Measurements of ratios ${ }^{137} \mathrm{Cs} / \mathrm{K}$ (pc./g), taken in 1961 during a slack period, showed values of 81 for the workers and 91 for controls. The corresponding values for 1962-63 wore 318 for workers and 293 for controls. There was, therefore, no difference between workers and controls in either period. However, the percentage of workers contaminated with more than 5 nc. of the fission products ${ }^{95} \mathrm{Zn}$ and its daughter, ${ }^{95} \mathrm{Nb}$, increased from 20 per cent in 1961 (highest value $50 \mathrm{nc}$.) to 70 per cent in 1962-63 (highest value $40 \mathrm{nc}$. ). The results of air sampling were approximately the same during both periods. Hence, although the usefulness of air sampling was confirmed, in that the body radioactivities due to ${ }^{95} \mathrm{Zn}$ and ${ }^{95} \mathrm{Nb}$ were negligible by comparison with the maximum permissible body burden of $20 \mu \mathrm{c}$., the results of air sampling were not sufficiently sensitive to direct attention to the fact that the intake of radioactive materials into the body had been increasing during the period of observations. This was only discovered by in vivo monitoring.

Mr. B. E. Godfrey (Radiological Protection Service) discussed the parameters required for estimation of radiation doses following single or protracted intake of radioactive material into the body. He pointed out that, when persons were measured for body radioactivity following accidents, it was seldom possible to determine all the parameters required. For example, the body radioactivity of the individual concerned was very frequently measured some time after the accident had occurred, so that the initial build-up of the radioactive material in the various organs and tissues was not observed. Very often it was not possible to determine the exact distribution of radioactive material in the body and impracticable to make repeated measurements on the individual to find the excretion pattern. In most cases, therefore, it was necessary to adopt some simple model for the distribution of the radioactive material in the body and its elimination. He referred to the model adopted by Vennart and Minski (1962) in which the pattern of elimination is described by a single exponential term and illustrated the use of such a model by describing some cases which had been measured in the whole-body counter at the Radiological Protection Service.

The first example concerned measurements of body radioactivity on three people who had accidentally taken in ${ }^{137} \mathrm{Cs}$ while at work. Measurcments had been made over a prolonged period starting a few weeks after the accident and for cach individual it was possible to fit the data to a single exponential function. The biological half-lives of ${ }^{137} \mathrm{Cs}$ were found to be 79 days, 118 days and 123 days (Taylor, Taylor and Vennart, 1962). The second example concerned measurements of ${ }^{131} \mathrm{I}$ in human thyroids follow. ing the Windscale Reactor accident of 1957, and also following the increase of nuclear weapon testing in 1961 In both cases it had been possible to fit a theoretical expression to the measured points on the assumption that radioactive iodine is eliminated from the thyroid according to a single exponential term (Maycock and Vennart, 1958, and Vennart, 1962). The third example concerned a patient injected with $25 \mu \mathrm{c}$. of ${ }^{22} \mathrm{Na}$ in a diagnostic test for exchangeable sodium, whose body radioactivity was later measured in the whole-body counter for a period extending from $2 \frac{1}{2}-4 \frac{1}{2}$ years after the test (Vennart, 1963). The measurements showed that about 0.35 per cent of the injected dose was eliminated from the body very slowly at 
a rate which could be described by a single exponential term. The effective half-period of elimination was 513 days, corresponding to a biological half-life of about 1,000 days. The value for the effective half-life was in accord with that of $\mathbf{4 4 5}$ days reported by Richmond (1958) and 475 days reported by Jagger, Hine, Cardarelli and Burrows (1963). The final example concerned two women whose body radioactivity had been measured during the period 5-12 weeks following the administration of ${ }^{131} \mathrm{I}$ in tests for thyroid function. The elimination of ${ }^{131} \mathrm{I}$ from the thyroid could be explained by a single exponential term corresponding to an iodine turnover of about 1.5 per cent per day, a value which is in reasonable agreement with that of 2 per cent per day quoted by Ziliotto (1961), but about twice the values quoted by Rosenburg (1958), Burns, Fish, Hackett and Hickey (1951), and Maurer (1961). However, it was necessary to be cautious in the interpretation of the results because these patients had been diagnosed as having anxiety states following their presentation with symptoms common to thyrotoxicosis. 'Thero was a possibility, therefore, that they might have slightly over-active thyroids.

In the discussion on this paper, Dr. Rundo referred to the use of collimated counters to investigate the distribution of radioactive materials in the body. Mr. Vennart doubted whether the degree of collimation would ever be sufficient to determine the activity in different organs of the body, except in very special cases such as the thyroid.

In a general discussion at the end of the symposium the main topic of interest concerned the problems of estimating the activities of $\beta$-emitting radionuclides in the body by measurement of bremsstrahlung in whole-body counters. It was clear from this that one of the chief limitations on the estimation of small $\beta$-activities was the presence of ${ }^{40} \mathrm{~K}$ and ${ }^{137} \mathrm{Cs}$ in the body. Degraded photons from both these radionuclides contribute to the bremsstrahlung spectrum of any $\beta$-emitter in the body and due allowance for this must be mado when estimating the $\beta$-activity. The uncortainty of an estimation of $\beta$-activity must, therefore, include the uncertainties of estimating both ${ }^{40} \mathrm{~K}$ and ${ }^{137} \mathrm{Cs}$. Furthermore, estimations of the contributions from ${ }^{40} \mathrm{~K}$ and ${ }^{137} \mathrm{Cs}$ involved considerations of several factors, including the weight of the subject and the effect of inhomogeneous distribution (Rundo, 1962), as well as the body content of the radionuclides. Lidén and McCall (1962) had made a careful study of the problem of measuring $\beta$-cmitters in the body and had estimated the minimum detectable body activity of ${ }^{90} \mathrm{Sr}$ in their apparatus to be $20-25 \mathrm{nc}$., of which a considerable fraction was due to the uncertainty of estimating the contribution from ${ }^{40} \mathrm{~K}$ and ${ }^{137} \mathrm{Cs}$. It was clear that the error of estimating $\beta$-emitters in the body would increase as the ${ }^{137} \mathrm{Cs}$ from fall-out increased. Dr. Rundo said that at present body contents of ${ }^{137} \mathrm{Cs}$ from fall-out were as high as they had ever been and he had recently measured $70 \mathrm{nc}$. of ${ }^{\circ 0} \mathrm{Sr}$ in one person with an estimated standard error of \pm 30 per cent.

At the conclusion of the symposium Mr. Binks dirceted attention to a difficulty which faced all those who had to deal with assessments of internal radiation exposure. This was to decide in what circumstances and with what frequency measurements of body radioactivity should be attempted. Clearly measurements need not be carried out in those cases where the amount of radionuclides used was so small that inhalation or ingestion of the whole amount could not lead to significant amounts relative to the maximum permissible body burdens. At higher levels it was not possible to relate the internal hazard with the? amount of radionuclide used since other factors, for example, the degree of containment, affected the situation.

It would seem that sample measurements of body radioactivity were necessary to establish the likely levels of uptake into the body. Where a need to carry out assessments of body radioactivity was established, the next question was the frequency of testing. Some of the papers presented during the symposium had indicated how some organizations had attempted to meet these difficulties. Any decisions reached about goneral policy would greatly affect the future national effort in assessing internal radiation exposures.

J. VENNART

\section{REFERENCES}

Anderson, E. C., Brit. ${ }_{a}^{5}$ J. Radiol. Suppl., 7, 27 (1956).

Baird, W. J., Tombropoulos, E. C. and Park, J. F., Diagnosis and Treatnent of Radioactive Poisoning, I.A.E.A. (1963).

Bird, P. R., and Burch, P. R. J., Phys. Med. and Biol., 2, 3, 217 (1958).

Burch, P. R. J., and Spiers, F. W., Nature, 172, 519 (1953).

Burns, W. H. J., Fish, W. A., Hackett, J. W., and Hickey, F. C., J. Appl. Physiol., 4, 15 (1951)

Dudley, R. A., Symp. Radioactivity in Man, Sept. 1962, North Western University, Chicago (1962)

Evans, R. D., Amer. J. Roent., 37, 368 (1937).

Furchner, J. F., Richmond, O. R., and Trafton, G. A., Los Alamos Scientifin Laboratory Report LAMS-2780, 69 (1962).

Hess, V. F., and McNiff, W. T., Amer. J. Roent., 57, 91 (1947).

Jagger, P. I., Hine, G. J., Cardarelli, J. A., and Burrows, B. A., J. Clin. Invest., 42, 1459, (1963).

Lidén, K. V.H., and McCall, R. C., Whole Body Counting (I.A.E.A., Viennil, 1962 ;

Marinelli, L. D., Brit. J. Radiol. Suppl. 7, 38 (1956)

Marinelli, L. D., Miller, C. L., May, H. A., and Rose, J. E., Adt. Biol. Met. Phys., 8 (Academic Press, New York, 1962).

Maurer, M. J., Fortschr, Rontgenstr., 96,129 (1962).

Maycock, G., MeCansh, S. W., and Vennart, J., Nature, 193, 516 (1962).

Maycock, G., Terry, s. W., Vennart, J., and Wise, M. E., Nature, 188, 355 (1960)

Maycock, G., and Vennart, J., Nature, 182, 1545 (1958).

Newton, D., Brit. J. Radiol., 36, 463 (1963).

Report of Committee II on Permissible Dose for Internal Radiation : Fecommendations of the International Commission on Radiological Protection. (Pergamon Press, 1958).

Richmond, C. R., Los Alamos Scientific Laboratory Report LA-2207 (1958), Rocsch, W. C., and Palmer, H. E., Health Physics, 8, 773 (1962).

Rosenburg, G., J. Clin. Endocrinol., 18, 516 (1958).

Rundo, J., Proc. Second U.N. Conf. Peaceful Uses of Atomic Energy, 23 101 (1958); Symposium on Whole Bedy Counting, I.A.E.A., Vienna, (1962); Brit. J. Radiol. (in the press).

Rundo, J., and Williams, K., Brit. J. Radiol., 34, 734 (1961).

Schlundt, H., Barker, H. H., and Flinn, F. B., Amer. J. Roent., 21, 345 (1929). Schlundt, H., Nerancy, J. T., and Morri, J. P., Amer. J. Roent., 30, 515 (1933).

Sievert, R. M., Ach. Fgs., 3, 337 (1951); Strahlentherapie, 99, 185 (1956).

Taylor, M. P., Taylor, D. M., ano Vennart, J., Phys. in Med. and Biol., n, 157 (1962).

Trott, N. G., Parnell, C. G., Hodt, H. J., and Entwistle, R. F., Rvit. J. Radiol., 36, 592 (1963).

Vennart, J., Brit. J. Radiol., 30, 55 (1957); Nature, 196, 740 (1962); Diarnosis and Treatment of Radioactive Poisoning (I.A.E.A., Vienna, 1963).

Vennart, J., Maycock, G., Godfrey, B. E., and Davics, B. I., Symposium on Assessment of Body Radioactivity in Man, Heidelberg, I.A.C.A., Vienna (in the press).

Vennart, J., and Minski, M., Brit. J. Radiol., 35, $3 \% 2$ (1962).

Wilson, A. R., Thesis, University of Leeds (1964).

Ziliotto, D., Acta Isotopica, 3, 281 (1961).

\title{
MELTING AND FREEZING*
}

\author{
By Prof. A. R. UBBELOHDE, C.B.E., F.R.S. \\ Department of Chemical Engineering and Chemical Technology, Imperial College of Science \\ and Technology, London, S.W.7
}

M ANY presont-day problems concerning melting and freezing can bo regarded as structural and statistical developments of the Boltzmann expression for the entropy of fusion, $S_{f}$ :

$$
S_{f}=R \ln W_{L} / W_{S}
$$

Some authors have postulated a critical melting limit, such that $S_{f} \rightarrow 0$, and there is then no discontinuous increase of entropy on passing from the solid to the liquid

* Substance of a lecture recently given before the Göttingen Akademie der Wissenschaften, Germany. 